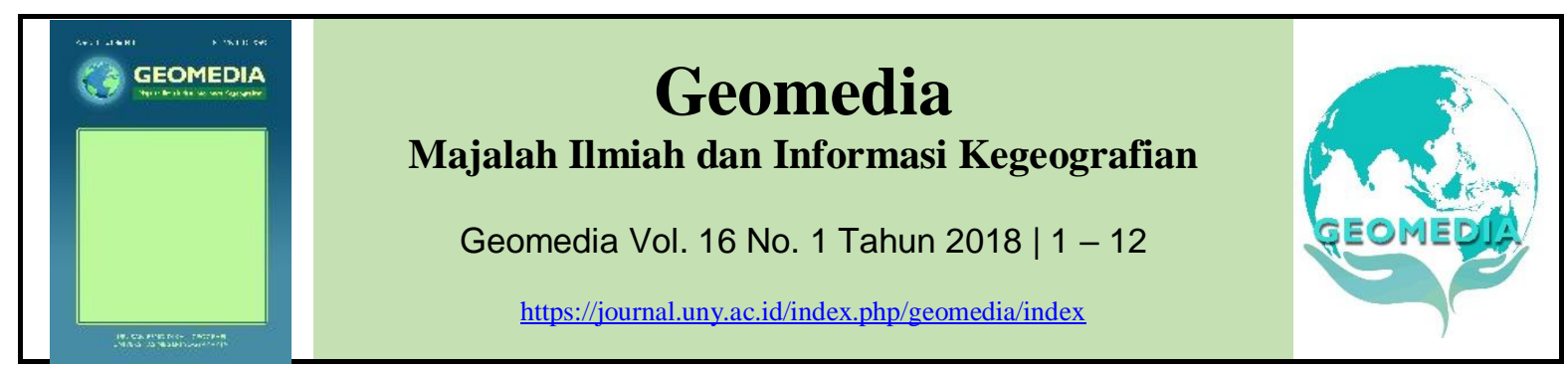

\title{
Kajian kemampuan metode neural network untuk klasifikasi penutup lahan dengan menggunakan Citra Landsat-8 OLI (kasus di Kota Yogyakarta dan sekitarnya)
}

\author{
Melania Swetika Rini* \\ Universitas Widya Dharma, Klaten, Indonesia \\ melanieajmala@gmail.com \\ *korespondensi penulis
}

\begin{tabular}{|c|c|}
\hline Informasi artikel & A B S T R A K \\
\hline $\begin{array}{l}\text { Kata kunci: } \\
\text { Neural network } \\
\text { Penutup lahan } \\
\text { Citra Landsat } 8 \text { OLI }\end{array}$ & $\begin{array}{l}\text { Penelitian ini bertujuan: Mengkaji akurasi metode neural network untuk } \\
\text { klasifikasi penutup lahan dengan menggunakan citra multispectral } \\
\text { Landsat } 8 \text { dan pengaruh input parameter pada metode neural network } \\
\text { terhadap hasil akurasi klasifikasi penutup lahan. Penelitian ini merupakan } \\
\text { penelitian berbasis data penginderaan jauh yang mencakup analisis } \\
\text { digital dan kerja lapangan. Analisis digital mencakup kegiatan menguji } \\
\text { kemampuan metode neural network/Multi Layer Perceptron (MLP) } \\
\text { dengan algoritma backpropagation untuk klasifikasi penutup lahan } \\
\text { berbasis citra penginderaan jauh Landsat } 8 \text {. Kerja lapangan dilakukan } \\
\text { untuk mengambil sampel penelitian dan menguji hasil akurasi klasifikasi } \\
\text { penutup lahan dengan metode jaringan syaraf. Uji akurasi menggunakan } \\
\text { akurasi keseluruhan, akurasi produser, akurasi pemakai dan analisis } \\
\text { kappa accuracy. Hasil penelitian menunjukan (1) nilai akurasi terbaik yang } \\
\text { diperoleh pada metode MLP dengan } 7 \text { kelas penutup lahan yaitu overall } \\
\text { accuracy } 76,69 \% \text {, kappa accuracy } 0,722 \text { serta waktu eksekusi } 1,25 \text { menit, } \\
\text { dengan kombinasi parameter yaitu } 1 \text { hidden layer; } 0,001 \text { learning rate; } 0,5 \\
\text { momentum factor; } 0,001 \text { RMS; dan } 15000 \text { iterasi; (2) Nilai parameter } \\
\text { learning rate } 0,001 \text { memberikan pengaruh nilai overall accuracy yang } \\
\text { rendah sedangkan nilai learning rate } 0,01 \text { memberikan nilai overall } \\
\text { accuracy yang baik. Iterasi } 15000 \text { lebih optimal dibandingkan nilai iterasi } \\
10000 \text { dan } 20000 \text { dalam pengaruhnya terhadap nilai akurasi hasil } \\
\text { klasifikasi penutup lahan. }\end{array}$ \\
\hline
\end{tabular}

Keywords:

Neural network

Land cover

Landsat $8 \mathrm{OLI}$ imagery

\section{A B S T R A C T}

This study aims: To assess the accuracy of neural network methods for classification of land cover by using Landsat 8 multispectral imagery and the influence of input parameters on neural network methods on the accuracy of land cover classification results. This research is a remote sensing data-based research that includes digital analysis and field work. Digital analysis includes activities to test the ability of neural network / Multi Layer Perceptron (MLP) methods with backpropagation algorithms for classification of Landsat 8 remote sensing image-based land cover. Field work was carried out to take research samples and test the results of the accuracy of classification of land cover with neural network methods. Test accuracy using overall accuracy, producer accuracy, user accuracy and kappa accuracy analysis. The results show: (1) the best accuracy value obtained in the MLP method with 7 land cover classes, $76.69 \%$ overall accuracy, 0.722 kappa accuracy and 1.25 minutes execution time, with a combination of parameters, namely 1 hidden layer; 0.001 learning rate; 0.5 momentum factor; $0.001 \mathrm{RMS}$; and 15,000 iterations. (2) Learning rate parameter value 0.001 gives a low overall accuracy value while the learning rate value 0.01 gives a good overall accuracy value. The 15000 iteration is more optimal than the 10000 and 20000 iteration values in its effect on the accuracy value of the classification of land cover. 


\section{Pendahuluan}

Ketersediaan informasi penutup lahan (land cover) yang akurat dilihat dari segi spasial maupun temporal merupakan komponen penting bagi pemerintah daerah dalam menyusun kegiatan perencanaan, pengelolaan dan pemantauan perubahan lingkungan. Beberapa contoh kegiatan yang membutuhkan informasi penutup lahan seperti Rencana Tata Ruang Wilayah (RTRW) Nasional, Propinsi dan Kabupaten/Kota, Kajian Lingkungan Hidup Strategis (KHLS), Monitoring Kawasan Hutan, Kajian Kebencanaan dan lain sebagainya. Mengingat sangat pentingnya informasi penutup lahan Dalam hal ini informasi mengenai penutup lahan yang komperhensif dan terbaru mutlak untuk diketahui.

Penutup lahan dan penggunaan memiliki pengertian yang berbeda, istilah penutup lahan berkaitan dengan jenis kenampakan yang ada dipermukaan bumi sedangkan penggunaan lahan berkaitan dengan kegiatan manusia pada lahan tertentu, (Lillesand and Kiefer, 1994). Informasi penutup lahan dapat diperoleh melalui data penginderaan jauh seperti foto udara dan citra satelit. Citra satelit merupakan salah satu produk dari teknologi penginderaan jauh yang banyak digunakan untuk memperoleh informasi penutup lahan karena memiliki resolusi spasial, spectral, dan temporal yang baik. Apabila dilihat dari sisi resolusi spectral, semakin banyak jumlah band atau saluran yang dimiliki oleh citra satelit maka semakin banyak informasi objek yang dapat diidentifikasi. Begitu juga dengan resolusi spasial, semakin besar resolusi spasial suatu citra maka semakin detail informasi objek yang diterima.

Salah satu citra satelit yang sering digunakan untuk kajian penutup lahan adalah Citra landsat. Pada tahun 2013 NASA meluncurkan satelit Landsat Data Continuity Mission (LDCM) yang dikenal dengan Landsat 8. Landsat 8 merupakan kelanjutan dari misi Landsat yang untuk pertama kali menjadi satelit pengamat bumi sejak tahun 1972 (Landsat 1). Landsat 8 tergolong satelit baru walaupun sebenarnya lebih cocok disebut sebagai satelit yang melanjutkan misi dari landsat 7, hal ini karena landsat 8 memiliki karakteristik yang mirip dengan landsat 7 hanya saja ada beberapa tambahan yang menjadi titik penyempurnaan dari landsat 7 seperti jumlah band, rentang spectrum dan nilai bit atau rentang nilai digital number.
Perkembangan teknologi satelit penginderaan jauh yang begitu cepat juga diikuti dengan perkembangan teknik ekstraksi informasi citra satelit penginderaan jauh. Salah satu teknik ekstraksi informasi citra adalah teknik klasifikasi. Saat ini telah berkembang metode klasifikasi multispektral yang bisa dilakukan melalui berbagai pendekatan diantaranya menurut Jensen (2005) hard classification atau soft classifaction. Sementara berdasarkan distribusi datanya dapat menggunakan algoritma pendekatan parametrik seperti maximum likelihood atau pendekatan non parametrik seperti jaringan syaraf tiruan (artificial neural network). Proses klasifikasi multispektral dapat diproses dengan menggunakan perangkat komputer. Berdasarkan tingkat otomatisasinya terdapat dua klasifikasi yaitu klasifikasi terselia (supervised classification) dan klasifikasi tak terselia (unsupervised classification) (Danoedoro, 2012)

Kemajuan dibidang komputerisasi menyebabkan munculnya teknik klasifikasi yang dikenal dengan nama soft computing. Soft computing merupakan model pendekatan untuk melakukan komputasi yang meniru akal manusia serta memiliki kemampuan untuk menalar dan belajar pada lingkungan yang penuh dengan ketidakpastian dan ketidaktepatan (Jang, 1997 dalam Kusumadewi dan Hartati, 2010). Salah satu komponen utama pembentuk soft computing adalah jaringan syaraf tiruan (neural network).

Neural Network sebenarnya mengadopsi kemampuan otak manusia yang mampu memberikan stimulasi/rangsangan, melakukan proses, dan memberikan output, (Kusumadewi, 2004). Output diperoleh dari variasi stimulasi dan proses yang terjadi di dalam otak manusia. Kemampuan manusia dalam memproses informasi merupakan hasil kompleksitas proses di dalam otak. Jaringan syaraf tiruan memiliki kelebihan dalam menggabungkan data spektral dan non spketral, kemampuannya mengingat data berapapun jumlahnya data yang dilatihkan (memorisasi) serta mengenali data yang belum dilatihkan (generalisasi), (Arif, 2011). Dalam dunia penginderaan jauh, neural network digunakan untuk mengekstrasi informasi dari citra satelit berbasis data nilai spectral dan data non spectral. Kemampuan neural network dalam menangani fenomena yang kompleks (heterogen) merupakan suatu keunggunalan dibandingkan dengan 
metode klasifikasi parametrik (konvensional) seperti maximum likelihood.

Penelitian ini bertujuan untuk mengetahui akurasi hasil klasifikasi penutup lahan menggunakan metode neural network pada citra landsat 8. Wilayah penelitian meliputi Kota Yogyakarta dan sekitarnya yang mencakup sebagian Kabupaten Bantul dan sebagian Kabupaten Sleman.

\section{Metode}

Penelitian ini menggunakan Citra digital Landsat 8 OLI perekaman tahun 2015 daerah perekaman Daerah Istimewa Yogyakarta (DIY). Dalam pengolahan data menggunakan perangkat lunak The Environmental Of Visual Image (ENVI) versi 5.1, IDRISI SELVA dan perangkat lunak pengolahan data spasial, yaitu ArcGIS 10.1. Tahapan pemrosesan citra dilakukan dengan melakukan koreksi radiometric terlebih dahulu dengan metode TOA (Top Of Atmospheric). Setelah itu melakukan koreksi geometric dengan mengambil 10 titik ikat (ground control points (GCPS)).

Jensen (2005) menjelaskan, ada 2 langkah utama dalam koreksi geometrik yaitu interpolasi spasial dan interpolasi intensitas. Interpolasi spasial berkaitan dengan koreksi posisi geometrik tiap piksel citra sesuai dengan posisi aslinya di permukaan bumi. Proses ini membutuhkan beberapa titik ikat (ground control points (GCPs)) sebagai referensi posisi yang dapat diperoleh dari citra yang telah terkoreksi, peta, atau pengukuran dengan piranti GNSS. maka semakin baik hasilnya. Sebagai hasilnya tiap citra yang telah dikoreksi dengan sistem proyeksi UTM memiliki metrik sesuai dengan peta dasar.

Skema klasifikasi yang digunakan dalam penelitian ini mengacu pada skema klasifikasi skema klasifikasi SNI 7645-1:2014 pada skala 1:50.000 dengan modifikasi. Penentuan sampel dilakukan dengan memilih area yang diketahui penutup lahannya secara pasti diketahui identitasnya baik itu berdasarkan pengetahuan lokal (local knowledge). Hal yang terpenting ketika pengambilan training set piksel adalah bukan banyaknya jumlah piksel pada satu area tetapi jumlah piksel yang banyak pada beberapa area. Piksel-piksel yang diambil sebaiknya juga memiliki karakteristik yang sama (Lillesand and Kiefer, 1994)

Jumlah minimal sampel untuk training area dalam penelitian ini yaitu 100 piksel untuk setiap kelas penutup lahan. Kesalahan dalam menentukan daerah contoh akan menyebabkan kesalahan hasil klasifikasi. Sehingga dalam mempermudah penentuan daerah contoh dibantu dengan citra resolusi tinggi yaitu Quickbird dan google earth.

Metode klasifikasi yang digunakan adalah Metode Klasifikasi Multilayer Perceptron (MLP). Proses klasifikasi MLP dilakukan setelah penentuan daerah contoh. Algoritma pelatihan yang digunakan pada klasifikasi ini yaitu backpropagation dengan supervised classification. Pada tahap ini proses klasifikasi dilakukan dengan simulasi beberapa parameter pada jaringan MLP. Proses simulasi MPL dilakukan dengan 16 simulasi dengan variasi parameter jaringan yang berbeda. Parameter jaringan disetting sedimikian rupa dengan tujuan untuk mendapatkan hasil klasifikasi MLP yang memiliki akurasi dan waktu eksekusi yang terbaik. Parameter-parameter jaringan yang ditentukan (kusumadewi S, 2004) yaitu:

1. Fungsi aktivasi: fungsi aktivasi yang digunakan adalah fungsi aktivasi sigmoid, hal ini didasari pada berbagai penelitian sebelumnya dengan membandingkan beberapa fungsi aktivasi dan menyimpulkan fungsi aktivasi sigmoid logistik sangat baik. Fungsi ini dengan mudah untuk membedakan dan dapat meminimalkan perhitungan kapasitas pelatihan, sinyal tak terbatas ke dalam sinyal terbatas dalam daerah ambang antara 0 sampai 1 .

2. Lapisan tersembunyi (hidden layer) adalah lapisan yang menerima respon bobot dari lapisan input untuk diteruskan pada lapisan output. Jumlah lapisan tersembunyi yang digunakan pada penelitian ini yaitu 1 dan 2 .

3. Learning rate, pada sistem ini, konstanta belajar yang digunakan secara default yaitu 0,001 .

4. Nilai momentum (training momentum), untuk mengatur besarnya efek perubahan bobot sebelumnya, nilai ini berada dalam interval nilai nol sampai satu. Nilai momentum lebih besar maka proses tahapan pelatihan akan semakin banyak dibandingkan dengan nilai momentum yang lebih kecil. Variasi nilai momentum akan dilakukan dalam simulasi. Nilai momentum yang divariasikan pada rentan 0,5-0,9

5. Iterasi merupakan suatu proses atau metode yang digunakan secara berulang-ulang (pengulangan) dalam menyelesaikan suatu permasalahan dalam klasifikasi. Dalam 
penelitian ini akan dicoba dengan jumlah iterasi 15.000 sampai 25.000 . Secara teori penambahan jumlah iterasi dapat meningkatkan akurasi dan mempengaruhi waktu eksekusi yang diperlukan dalam pelatihan dan pengujian jaringan untuk klasifikasi.

6. Nilai RMS, nilai toleransi selama pelatiahan akan terhenti. Nilai ini akan digunakan sebagai batas iterasi. Iterasi akan berhenti jika nilai RMS < nilai batas toleransi yang ditetapkan pada jaringan ataupun jumlah epoch yang telah mencapai batas yang telah ditentukan. Pada penelitian ini RMS yang ditentukan sebesar 0,001 dengan harapan hasil klasifikasi semakin baik.

Setiap hasil simulasi klasifikasi MLP akan dilakukan pengujian akurasi dan waktu eksekusi. Uji akurasi dilakukan untuk menilai ketelitian data hasil klasifikasi. Tahap ini diawali dengan penentuan sampel di lapangan. Teknik pengambilan sampel dengan metode purposive random sampling, yaitu sampel diambil secara acak dengan pertimbangan pengetahuan lokal dan keterjangkauan di lapangan. Sampel yang diperoleh digunakan untuk training area dan uji akurasi pada setiap kelas penutup lahan. Selanjutnya uji akurasi dengan membuat confusion matrix/error matrix (matriks kesalahan). Matriks kesalahan ini membandingakan hubungan antara data lapangan yang telah diketahui dengan hasil proses klasifikasi. Uji akurasi yang akan diterapkan dengan menggunakan akurasi keseluruhan (overall accuracy), akurasi penghasil (producer accuracy), akurasi pemakai (user accuracy) dan Kappa accuracy (K). McCoy (2005) menjelaskan suatu hasil interpretasi dapat digunakan keperluan analisis jika tingkat ketelitiannya mencapai minimal $80-85 \%$

\section{Hasil dan pembahasan}

Penelitian ini dilakukan dengan mengambil studi kasus di Kota Yogyakarta dan sekitarnya. Dalam proses pengambilan daerah contoh digunakan perangkat lunak ENVI 5.1. dengan pertimbangan karena perangkat lunak ini dianggap paling fleksibel. Selanjutnya untuk proses dan eksekusi klasifikasi MLP digunakan perangkat lunak IDRISI SELVA. Adapun untuk proses layout peta hasil klasifikasi digunakan peragkat lunak ARCGIS 10.1. Tabel 1 berikut ini menunjukkan jumlah piksel daerah contoh dalam penelitian ini.

Tabel 1. Jumlah Piksel Daerah Contoh

\begin{tabular}{llll}
\hline No & Kelas Penutup Lahan & Kode & $\begin{array}{l}\text { Jumlah } \\
\text { Piksel }\end{array}$ \\
\hline 1 & $\begin{array}{l}\text { Lahan } \\
\text { Terbangun/Bangunan }\end{array}$ & $\mathrm{Lb}$ & 271 \\
\hline 2 & Tanah Terbuka & $\mathrm{Tk}$ & 131 \\
\hline 3 & $\begin{array}{l}\text { Rumput/Semak } \\
\text { Belukar }\end{array}$ & $\mathrm{Sb}$ & 193 \\
\hline 4 & Vegetasi Pohon & $\mathrm{Vp}$ & 193 \\
\hline 5 & Vegetasi Sawah & $\mathrm{Vs}$ & 200 \\
\hline 6 & Jaringan Jalan & $\mathrm{Jl}$ & 212 \\
\hline 7 & Tubuh Air/Sungai & $\mathrm{Ta}$ & 102 \\
\hline
\end{tabular}

Sampel yang telah diambil sebagai training area selanjutnya dikontrol melalui uji keterpisahan atau uji separabilitas pada masing-masing kelas penutup lahan. Uji separabilitas dihitung dengan menggunakan algoritma transformed divergence (TD). Nilai transformed divergence (TD) antara 1,900-2,000 memiliki keterpisahan yang baik, sedangkan di bawah 1,700 merupakan hasil keterpisahan yang kurang baik (poor), yang dimungkinkan piksel tersebut adalah piksel campuran, (Jensen, 2005). Hasil uji separabilitas ditunjukkan oleh Tabel 2.

Tabel 2. Nilai Indeks Separabilitas 7 Kelas Penutup Lahan

\begin{tabular}{|c|c|c|c|c|c|c|c|}
\hline \multirow{2}{*}{\multicolumn{8}{|c|}{$\mathrm{Sb}$}} \\
\hline & & & & & & & \\
\hline Tk & 1.900 & & & & & & \\
\hline $\mathrm{Sb}$ & 1.995 & 1.845 & & & & & \\
\hline$V p$ & 1.999 & 1.999 & 1.993 & & & & \\
\hline Vs & 1.999 & 1.999 & 1.999 & 1.885 & & & \\
\hline $\mathrm{Jl}$ & 1.841 & 1.949 & 1.999 & 1.999 & 1.996 & & \\
\hline $\mathrm{Ta}$ & 1.999 & 1.998 & 1.998 & 1.977 & 1.897 & 1.969 & \\
\hline
\end{tabular}

Berdasarkan data yang terdapat dalam Tabel 2, nilai indeks separabilitas setiap sampel memiliki nilai keterpisahan yang baik dengan nilai maksimum 1.999 dan minimum 1.841 artinya tidak ada nilai keterpisahan yang di bawah 1.700 .

Penelitian ini dilakukan dengan melakukan 16 simulasi jaringan MLP dengan cara mengatur nilai parameter jaringan. Hasil simulasi parameter MLP akan dihitung nilai akurasinya dan waktu eksekusinya. Tujuannya adalah untuk menilai seberapa besar tingkat kesalahan dan ketelitian dari hasil klasifikasi penutup lahan dengan membandingkan data lapangan dan hasil klasifikasi. Simulasi MLP Pada 7 Saluran (Spektral) ditunjukkan oleh Tabel 3. 
Tabel 3

Simulasi MLP Pada 7 Saluran (Spektral)

\begin{tabular}{ccccccccccc}
\hline No & $\begin{array}{c}\text { Kode } \\
\text { Simulasi }\end{array}$ & HL & LR & MF & RMS & Iterasi & $\begin{array}{c}\text { Akurasi } \\
\text { MLP } \\
(\%)\end{array}$ & $\begin{array}{c}\text { overall } \\
\text { accuracy } \\
(\%)\end{array}$ & $\begin{array}{c}\text { Kappa } \\
\text { Accuracy } \\
(\%)\end{array}$ & $\begin{array}{c}\text { Waktu } \\
\text { (menit) }\end{array}$ \\
\hline 1 & MLP1 & 1 & 0,001 & 0,5 & 0,001 & 10000 & 62,17 & 60,47 & 0.474 & 1 \\
\hline 2 & MLP2 & 1 & 0,01 & 0,5 & 0,001 & 10000 & 82,54 & 75,81 & 0,747 & 1 \\
\hline 3 & MLP3 & 1 & 0,05 & 0,5 & 0,001 & 10000 & 83,61 & 74,92 & 0,702 & 1 \\
\hline 4 & MLP4 & 1 & 0,001 & 0,6 & 0,001 & 10000 & 63,71 & 57,52 & 0,494 & 1 \\
\hline 5 & MLP5 & 1 & 0,01 & 0,6 & 0,001 & 10000 & 84,38 & 75,51 & 0,709 & 1 \\
\hline 6 & MLP6 & 1 & 0,05 & 0,6 & 0,001 & 10000 & 78,10 & 75,51 & 0,708 & 1 \\
\hline 7 & MLP7 & 1 & 0,001 & 0,5 & 0,001 & 15000 & 65,70 & 57,22 & 0,491 & 1,25 \\
\hline $\mathbf{8}$ & MLP8 & $\mathbf{1}$ & $\mathbf{0 , 0 1}$ & $\mathbf{0 , 5}$ & $\mathbf{0 , 0 0 1}$ & $\mathbf{1 5 0 0 0}$ & 83,92 & $\mathbf{7 6 , 6 9}$ & 0,722 & 1,25 \\
\hline 9 & MLP9 & 1 & 0,05 & 0,5 & 0,001 & 15000 & 84,53 & 72,86 & 0,678 & 1,21 \\
\hline 10 & MLP10 & 1 & 0,001 & 0,5 & 0,001 & 20000 & 69,07 & 63,42 & 0,564 & 1,46 \\
\hline 11 & MLP11 & 1 & 0,01 & 0,5 & 0,001 & 20000 & 83,61 & 76,10 & 0,716 & 1,51 \\
\hline 12 & MLP12 & 1 & 0,05 & 0,5 & 0,001 & 20000 & 84,69 & 73,15 & 0,682 & 1,34 \\
\hline 13 & MLP13 & 2 & 0,001 & 0,5 & 0,001 & 10000 & 63,24 & 56,32 & 0,438 & 3 \\
\hline 14 & MLP14 & 2 & 0,01 & 0,5 & 0,001 & 10000 & 82,39 & 75,22 & 0,706 & 1,28 \\
\hline $\mathbf{1 5}$ & MLP15 & $\mathbf{2}$ & $\mathbf{0 , 0 1}$ & $\mathbf{0 , 5}$ & $\mathbf{0 , 0 0 1}$ & $\mathbf{1 5 0 0 0}$ & $\mathbf{8 6 , 8 3}$ & $\mathbf{7 4 , 3 3}$ & $\mathbf{0 , 6 9 5}$ & $\mathbf{2 , 1 2}$ \\
\hline 16 & MLP16 & $\mathbf{2}$ & 0,01 & 0,5 & 0,001 & 20000 & 83,92 & 73,45 & 0,684 & 2,48 \\
\hline
\end{tabular}

Sumber : Pengolahan Citra, 2016

Keterangan: HL (Hidden Layer); LR (learning rate); MF (Momentum Factor); RMS (RMS exit criteria);

Tabel hasil simulasi menunjukan bahwa nilai learning rate atau laju pembelajaran 0,001 tidak memberikan hasil akurasi yang baik, tetapi sebaliknya justru memiliki hasil akurasi yang tidak baik yaitu pada simulasi MLP1 dengan akurasi MLP sebesar $62,17 \%$ dan overall accuracy 60,47 $\%$, simulasi MLP4 dengan akurasi MLP sebesar $63,71 \%$ dan overall accuracy $57,52 \%$, simulasi MLP7 dengan akurasi MLP sebesar $65,70 \%$ dan overall accuracy $57,22 \%$, simulasi MLP10 dengan akurasi MLP sebesar $69,07 \%$ dan overall accuracy $63,42 \%$, dan simulasi MLP13 dengan akurasi MLP sebesar $63,24 \%$ dan overall accuracy $56,32 \%$.

Hasil akurasi MLP dan overall accuracy pada tabel simulasi di atas menunjukan bahwa nilai akurasi MLP yang tinggi tidak selalu memberikan nilai overall accuracy yang tinggi pula, hal ini disebabkan karena resolusi spasial citra yang digunakan adalah 30 meter dimana banyak objek penutup lahan di daerah perkotaan yang saling berdekatan sehingga pengambilan sampel penutup lahan tidak $100 \%$ homogen. Artinya banyak terdapat piksel campuran atau 1 piksel di citra belum mewakili kenampakan satu objek di lapangan. Selain itu ketidakstabilan software IDRISI SELVA juga menyebabkan terjadinya perbedaan pada nilai hasil akurasi MLP dan overall accuracy.
Simulasi MLP dengan 7 kelas penutup lahan pada 7 saluran spectral landsat 8 OLI menunjukan hasil yang beragam. Dari 16 simulasi yang dilakukan, akurasi MLP terbaik di dapat pada simulasi MLP15 dengan nilai akurasi sebesar $86,83 \%$ akan tetapi nilai overall accuracy nya bukan yang paling tinggi dimana nilai overall accuracy yang diperoleh sebesar $74,33 \%$ yang terpaut $2,36 \%$ dari nilai overall accuracy tertinggi yang terdapat pada simulasi MLP8. Simulasi MLP15 menggunakan 2 hidden layer dengan nilai learning rate 0,01 , momentum factor 0,5 dan iterasi 15.000 ternyata memiliki nilai overall accuracy yang lebih kecil dibandingkan dengan simulasi pada MLP14 yang memiliki parameter jaringan yang sama kecuali pada nilai iterasinya sebesar 10.000. Simulasi MLP14, MLP15 dan MLP16 menggunakan learning rate 0,01 , momentum factor 0,5 , RMS 0,001 dengan iterasi yang berbeda yaitu 10.000, 15.000 dan 20.000 memperlihatkan nilai overall accuracy yang optimal pada iterasi 10.000 dan semakin menurun pada iterasi 15.000 dan 20.000 . Hal ini menunjukan bahwa nilai iterasi yang besar tidak selalu memberikan akurasi yang baik. Gambar 1 menunjukkan tampilan hasil klasifikasi penutup lahan pada simulasi 15 dengan nilai akurasi MLP tertinggi. 


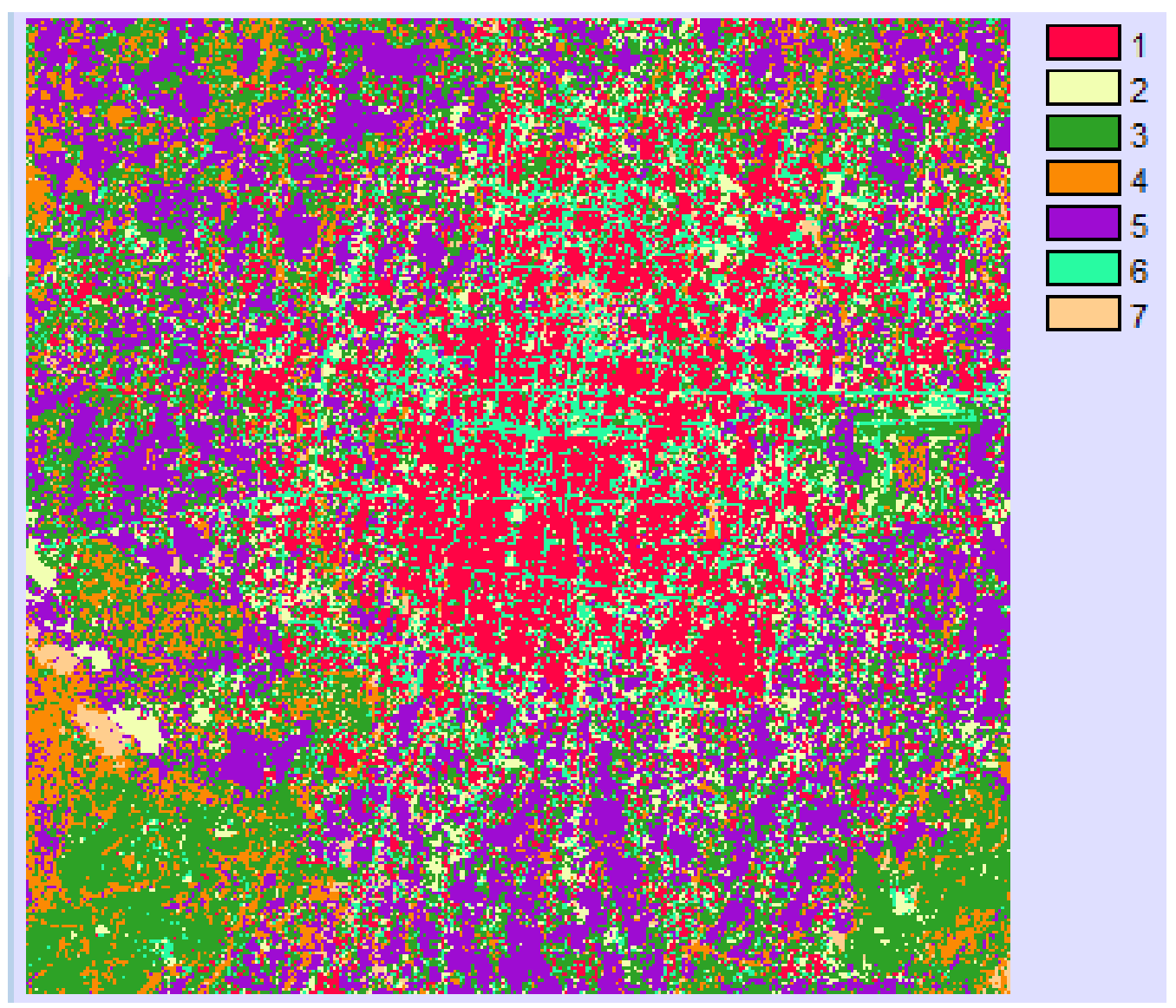

Gambar 1 Tampilan Hasil Klasifikasi Penutup Lahan Pada Simulasi MLP15

Keterangan : 1 : Lahan Terbangun, 2 : Tanah Terbuka, 3 : Rumput/Semak Belukar, 4 : Vegetasi Pohon, 5 : Vegetasi Sawah, 6 : Jaringan Jalan, 7 Tubuh Air/Sungai

Simulasi MLP dengan overall accuracy tertinggi dijumpai pada simulasi MLP8 dengan nilai overall accuracy sebesar $76,69 \%$ dan nilai index kappa 0,722. Parameter yang digunakan pada simulasi MLP8 yaitu 1 hidden layer, 0,01 learning rate, 0,5 momentum factor, 0,001 RMS dan 15.000 iterasi. Hasil klasifikasi penutup lahan pada simulasi MLP8 dapat dilihat pada Gambar 2.

Nilai kappa accuracy tertinggi diperoleh pada simulasi MLP2 dengan nilai kappa 0,747 dan waktu training parameter hanya 1 menit. Parameter yang digunakan pada simulasi MLP2 yaitu 1 hidden layer, 0,01 learing rate, 0,5 momentum factor, 0,001 RMS dan 10.000 iterasi. Tampilan hasil klasifikasi penutup lahan pada MLP2 dengan 7 saluran spectral Landsat 8 OLI ditunjukkan oleh Gambar 3.

Hasil uji akurasi klasifikasi penutup lahan pada 3 simulasi MLP yang dipilih berdasarkan nilai akurasi MLP tertinggi (simulasi MLP15), overall accuracy tertinggi (simulasi MLP8) dan kappa accuracy tertinggi (simulasi MLP2). Secara berturut-turut nilai producer's accuracy, user's accuracy dapat dilihat pada Tabel 4 hingga 9 Tabel 4.

Matriks Kesalahan (error Matrix) Pada Simulasi MLP15 untuk 7 Kelas Penutup Lahan

\begin{tabular}{|c|c|c|c|c|c|c|c|c|c|}
\hline \multirow{13}{*}{$\begin{array}{c}\text { Hasil } \\
\text { Klasifik } \\
\text { asi }\end{array}$} & \multicolumn{9}{|c|}{ Data Acuan / Data Lapangan } \\
\hline & & $\mathrm{L}$ & $\mathrm{T}$ & $\mathrm{S}$ & $\mathrm{V}$ & $\mathrm{V}$ & ال ال & $\mathrm{T}$ & \\
\hline & & $b$ & $\mathrm{k}$ & $\mathrm{b}$ & $p$ & $\mathrm{~S}$ & & a & \\
\hline & $\begin{array}{l}L \\
b\end{array}$ & $\begin{array}{l}3 \\
2\end{array}$ & 3 & 0 & 0 & 0 & 3 & 0 & 38 \\
\hline & $\begin{array}{l}\mathrm{T} \\
\mathrm{k}\end{array}$ & 0 & $\begin{array}{l}1 \\
3\end{array}$ & 0 & 0 & 1 & 0 & 0 & 14 \\
\hline & $\begin{array}{l}\mathrm{S} \\
\mathrm{b}\end{array}$ & 0 & $\begin{array}{l}1 \\
0\end{array}$ & $\begin{array}{l}4 \\
3\end{array}$ & 2 & 2 & 1 & 0 & 58 \\
\hline & $\begin{array}{l}\mathrm{V} \\
\mathrm{p}\end{array}$ & 0 & 1 & 5 & $\begin{array}{l}4 \\
4\end{array}$ & 9 & 0 & 4 & 63 \\
\hline & V & 0 & 0 & 0 & 2 & 4 & 0 & 5 & 75 \\
\hline & $\mathrm{S}$ & & & & 5 & 5 & & & \\
\hline & ال ال & 1 & 1 & 0 & 0 & 0 & $\begin{array}{l}4 \\
9\end{array}$ & 4 & 55 \\
\hline & $\begin{array}{l}\mathrm{T} \\
\mathrm{a}\end{array}$ & 0 & 0 & 0 & 0 & 6 & 4 & $\begin{array}{l}2 \\
6\end{array}$ & 36 \\
\hline & & 3 & 2 & 4 & 7 & 6 & 5 & 3 & 33 \\
\hline & & 3 & 8 & 8 & 1 & 3 & 7 & 9 & 9 \\
\hline
\end{tabular}

Sumber : Pengolahan Citra, 2016 


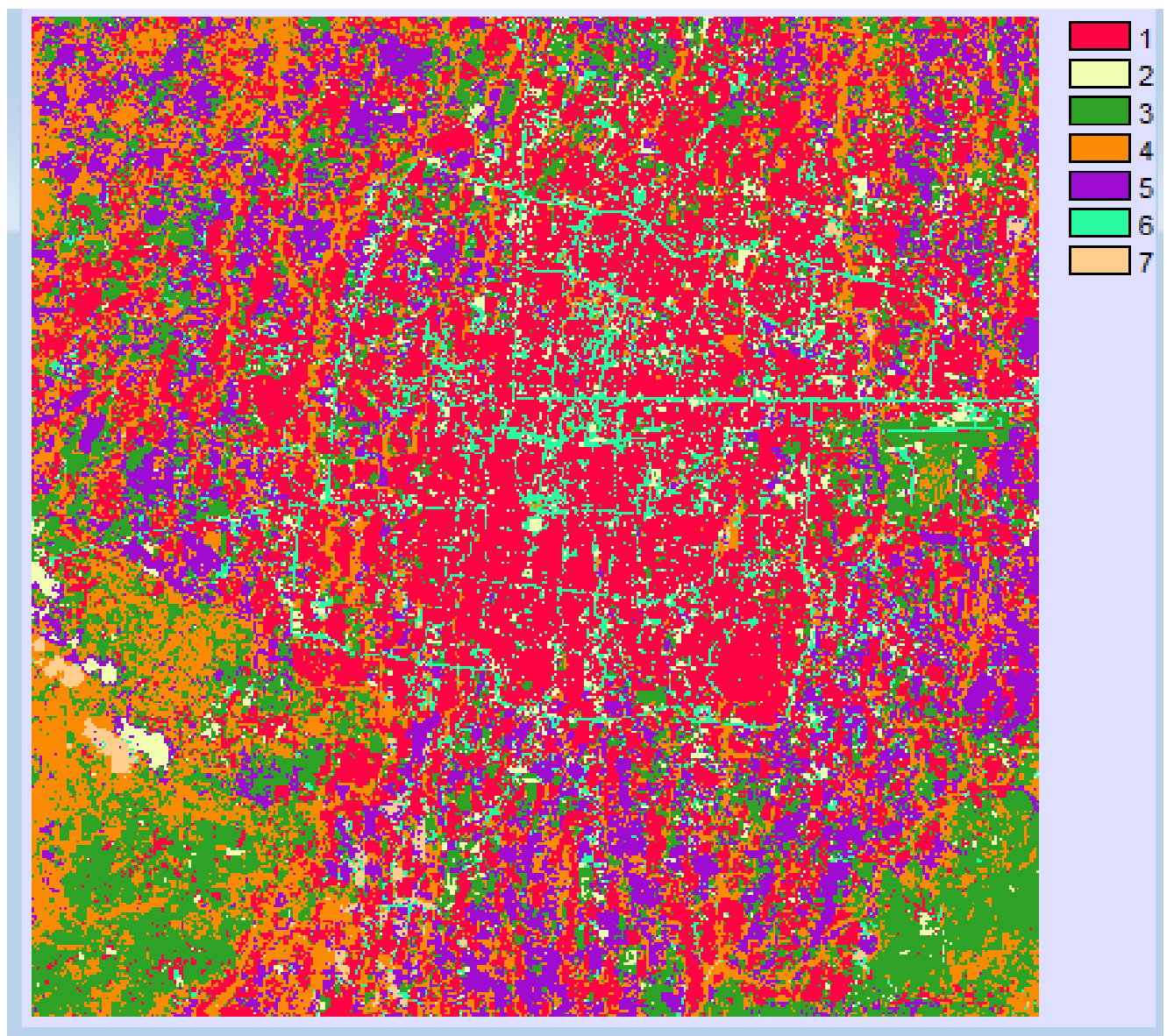

Gambar 2. Tampilan Hasil Klasifikasi Penutup Lahan Pada Simulasi MLP8

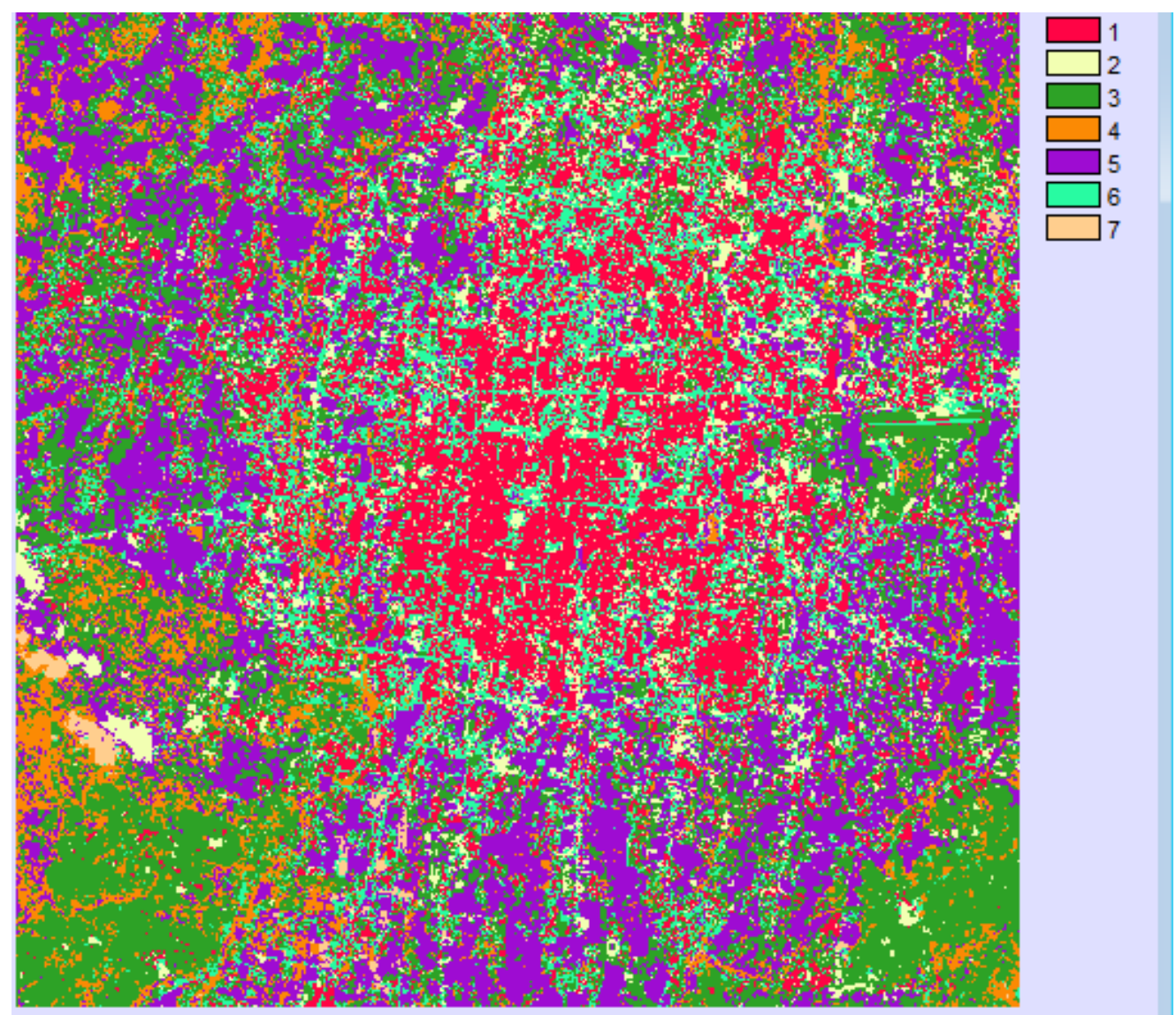

Gambar 3. Tampilan Hasil Klasifikasi Penutup Lahan Pada Simulasi MLP2 
Tabel 5

Nilai producer's accuracy dan user's accuracy Pada Simulasi MLP15 untuk 7 Kelas

Penutup Lahan

\begin{tabular}{lllll}
\hline $\begin{array}{l}\text { Ke } \\
\text { las }\end{array}$ & \multicolumn{2}{l}{$\begin{array}{l}\text { Producer's } \\
\text { Accuracy }\end{array}$} & User Accuracy \\
\cline { 2 - 5 } & $\begin{array}{l}\text { Akurasi } \\
(\%)\end{array}$ & $\begin{array}{l}\text { Omisi } \\
\text { Kesalahan }\end{array}$ & $\begin{array}{l}\text { Akurasi } \\
(\%)\end{array}$ & $\begin{array}{l}\text { Komisi } \\
\text { Kesalahan }\end{array}$ \\
\hline $\mathrm{Lb}$ & 97.00 & 3.0 & 84.21 & 15.79 \\
\hline $\mathrm{Tk}$ & 46.43 & 53.57 & 92.86 & 7.14 \\
\hline $\mathrm{Sb}$ & 89.48 & 10.42 & 74.14 & 25.86 \\
\hline $\mathrm{Vp}$ & 61.07 & 38.03 & 69.84 & 30.16 \\
\hline $\mathrm{Vs}$ & 71.43 & 28.57 & 60.0 & 40.0 \\
\hline $\mathrm{Jl}$ & 85.06 & 14.04 & 89.09 & 10.91 \\
\hline $\mathrm{Ta}$ & 66.67 & 33.33 & 72.22 & 27.78 \\
\hline
\end{tabular}

Sumber : Pengolahan Citra, 2016

Tabel 6

Matriks Kesalahan (error Matrix) Pada Simulasi MLP8 dengan Nilai Overall Accuracy Tertinggi untuk 7 Kelas Penutup Lahan

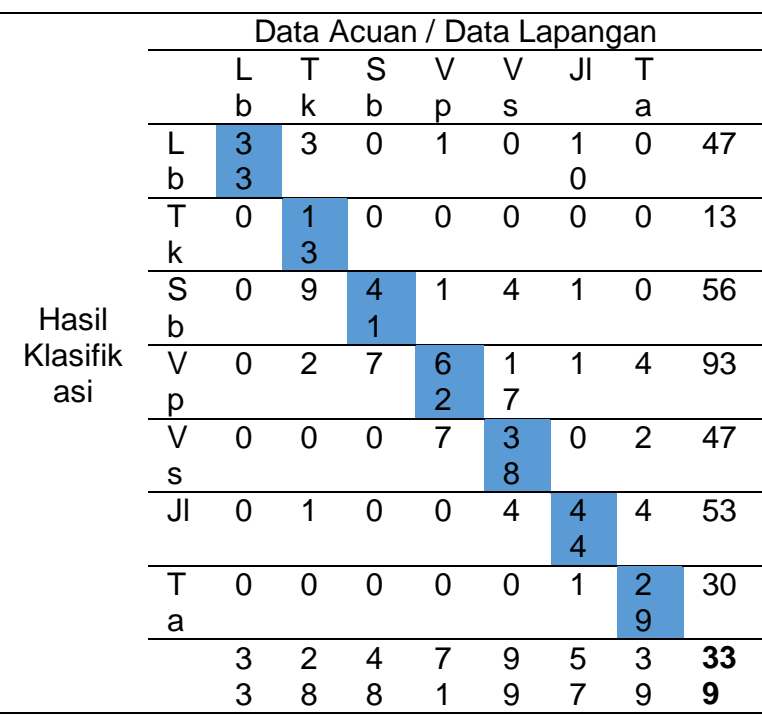

Sumber : Pengolahan Citra, 2016

Dari Tabel 5 dapat dilihat bahwa akurasi tertinggi untuk 7 kelas penutup lahan di daerah penelitian menggunakan metode neural network dengan arsitektur jaringan MLP ditunjukan pada kelas lahan terbangun dengan tingkat akurasi penghasil atau producer's accuracy sebesar $97,0 \%$ dengan nilai omisi kesalahan sebesar 3.0 $\%$. Sedangkan akurasi penghasil terendah terdapaat pada kelas tanah terbuka/lahan kosong yaitu sebesar $46,43 \%$ dengan nilai omisi kesalahan sebesar 53,57\%. Pada tingkat akurasi pengguna atau user's accuracy akurasi tertinggi terdapat pada kelas tanah terbuka/lahan kosong yaitu sebesar 92,86 \% dengan nilai komisi kesalahan sebesar $7,14 \%$, sedangkan akurasi pengguna terendah terdapat pada kelas vegetasi sawah yaitu sebesar $60.0 \%$ dengan nilai komisi kesalahan sebesar $40 \%$.

Tabel 7.

Nilai producer's accuracy dan user's accuracy

Pada Simulasi MLP8 dengan Nilai Overall

Accuracy Tertinggi untuk 7 Kelas Penutup Lahan

\begin{tabular}{lllll}
\hline Ke & \multicolumn{2}{l}{ Producer's Accuracy } & \multicolumn{2}{l}{ User Accuracy } \\
\cline { 2 - 5 } & $\begin{array}{l}\text { Akurasi } \\
(\%)\end{array}$ & $\begin{array}{l}\text { Omisi } \\
\text { Kesalahan }\end{array}$ & $\begin{array}{l}\text { Akurasi } \\
(\%)\end{array}$ & $\begin{array}{l}\text { Komisi } \\
\text { Kesalahan }\end{array}$ \\
\hline $\mathrm{Lb}$ & 100 & 0 & 29.79 & 60.21 \\
\hline $\mathrm{Tk}$ & 53.57 & 46.43 & 0 & 0 \\
\hline $\mathrm{Sb}$ & 14.58 & 85.42 & 26.79 & 63.21 \\
\hline $\mathrm{Vp}$ & 12.68 & 87.32 & 33.33 & 66.67 \\
\hline $\mathrm{Vs}$ & 39.68 & 60.32 & 19.15 & 80.85 \\
\hline $\mathrm{Jl}$ & 22.81 & 77.19 & 16.98 & 83.02 \\
\hline $\mathrm{Ta}$ & 25.64 & 74.36 & 3.33 & 96.67 \\
\hline \multicolumn{5}{l}{ Sumber : Pengolahan Citra, 2016 }
\end{tabular}

Tabel 8

Matriks Kesalahan (error Matrix) Pada Simulasi MLP2 dengan Nilai Kappa Accuracy Tertinggi untuk 7 Kelas Penutup Lahan

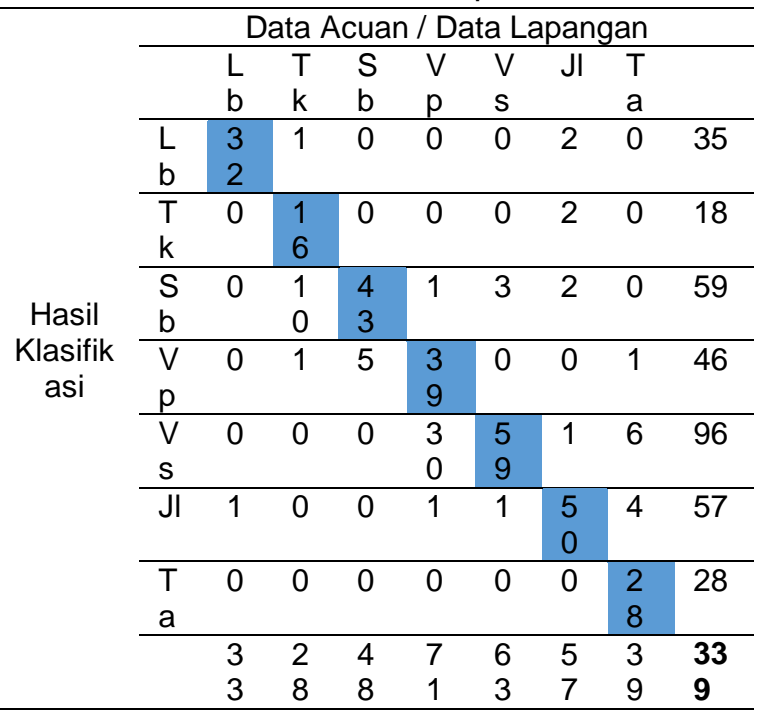

Sumber : Pengolahan Citra, 2016

Dari tabel 7 dapat dilihat bahwa akurasi penghasil atau producer's accuracy tertinggi untuk 7 kelas penutup lahan di daerah penelitian menggunakan metode neural network dengan arsitektur jaringan MLP ditunjukan pada kelas lahan terbangun dengan tingkat akurasi penghasil atau producer's accuracy sebesar 100,0\% dengan omisi kesalahan sebesar $0 \%$. sedangkan akurasi penghasil terendah terdapaat pada kelas vegetasi pohon yaitu sebesar $12,68 \%$ dengan 
omisi kesalahan sebesar 87,32 \%. Pada tingkat akurasi pengguna atau user's accuracy, akuras tertinggi terdapat pada kelas vegetasi pohon yaitu sebesar 33,33\% dengan komisi kesalahan sebesar 66,67\%, sedangkan akurasi pengguna terendah terdapat pada kelas tanah terbuka/lahan kosong yaitu $0 \%$ dengan nilai komisi kesalahan sebesar $0 \%$

Tabel 9

Nilai producer's accuracy dan user's accuracy

Pada Simulasi MLP2 dengan Nilai Kappa Accuracy Tertinggi untuk 7 Kelas Penutup Lahan

\begin{tabular}{lllll}
\hline $\begin{array}{l}\text { Ke } \\
\text { las }\end{array}$ & \multicolumn{2}{l}{$\begin{array}{l}\text { Producer's } \\
\text { Accuracy }\end{array}$} & User Accuracy \\
\cline { 2 - 5 } & $\begin{array}{l}\text { Akurasi } \\
(\%)\end{array}$ & $\begin{array}{l}\text { Omisi } \\
\text { Kesalahan }\end{array}$ & $\begin{array}{l}\text { Akurasi } \\
(\%)\end{array}$ & $\begin{array}{l}\text { Komisi } \\
\text { Kesalahan }\end{array}$ \\
\hline $\mathrm{Lb}$ & 96.97 & 3.03 & 91.43 & 8.57 \\
\hline $\mathrm{Tk}$ & 57.14 & 42.86 & 88.89 & 11.11 \\
\hline $\mathrm{Sb}$ & 89.58 & 10.42 & 72.88 & 27.12 \\
\hline $\mathrm{Vp}$ & 54.93 & 45.07 & 84.78 & 15.22 \\
\hline $\mathrm{Vs}$ & 93.65 & 6.35 & 62.46 & 38.54 \\
\hline $\mathrm{Jl}$ & 87.72 & 12.28 & 87.72 & 12.28 \\
\hline $\mathrm{Ta}$ & 71.79 & 28.21 & 100 & 0 \\
\hline \multicolumn{5}{c}{ Sumber : Pengolahan Citra, 2016 }
\end{tabular}

Dari tabel 9 dapat dilihat bahwa akurasi penghasil atau producer's accuracy tertinggi untuk 7 kelas penutup lahan di daerah penelitian menggunakan metode neural network dengan arsitektur jaringan MLP ditunjukan pada kelas lahan terbangun dengan tingkat akurasi penghasil atau producer's accuracy sebesar 96,97\% dengan omisi kesalahan sebesar $3.03 \%$. sedangkan akurasi penghasil terendah terdapaat pada kelas vegetasi pohon yaitu sebesar 54,93 \% dengan omisi kesalahan sebesar 45,07 \%. Pada tingkat akurasi pengguna atau user's accuracy, akurasi tertinggi terdapat pada kelas tubuh air yaitu sebesar $100 \%$ dengan komisi kesalahan sebesar $0 \%$, sedangkan akurasi pengguna terendah terdapat pada kelas vegetasi sawah yaitu $62,46 \%$ dengan nilai komisi kesalahan sebesar 38,54\%.

Berdasarkan hasil simulasi MLP pada Tabel 3, sangat jelas bahwa nilai akurasi dari klasifikasi penutup lahan diseluruh model jaringan MLP dengan variasi parameter internal yang berbeda sangatlah berpengaruh. Khususnya di empat parameter yang divariasikan yaitu hidden layer (lapisan tersembunyi), learning rate (laju pembelajaran), training momentum (faktor momentum) dan iterasi yang dilakukan dengan cara mengubah nilai dari setiap parameter tersebut. Parameter hidden layer berpengaruh terhadap waktu dan hasil akurasi klasifikasi penutup lahan dimana jumlah hidden layer satu lebih baik dibandingkan dengan hidden layer dua baik dari sisi waktu maupun hasil akurasi klasifikasi yang terlihat pada hasil simulasi MLP8 dan MLP15. Pada MLP8 menggunakan satu hidden layer dan MLP15 menggunakan dua hidden layer dengan nilai parameter learning rate, momentum factor, RMS dan iterasi mempunyai nilai yang sama. Waktu yang dibutuhkan dalam proses pembelajaran pada simulasi MLP8 lebih baik dari simulasi MLP15 dengan waktu proses selama 1,25 menit sedangkan pada simulasi MLP15 selama 2,12 menit, dengan demikian ada selisih waktu 47 detik. Begitu juga dengan hasil overall accuracy pada simulasi MLP8 lebih besar dibandingkan MLP15 dengan masing-masing nilai overall accuracy sebesar 76,69 dan 74,33.

Penggunaan parameter learning rate dengan tiga kombinasi nilai yaitu $0,001,0,01$ dan 0,05 dengan tujuan untuk melihat pada nilai berapa learning rate akan optimum dan memberikan akurasi terbaik. Learning rate yang terlalu tinggi dapat menyebabkan algoritma tidak stabil yang berpengaruh terhadap hasil klasifikasi. Sebaliknya jika learing rate terlalu rendah akan menyebabkan algoritma akan semakin lama mencapai konvergen. Dari hasil simulasi MLP pada table 3 terlihat bahwa nilai learning rate 0,001 memiliki nilai overall accuracy terendah disetiap simulasi dibandingkan dengan nilai learning rate 0,01 dan 0,05 . Sedangkan untuk nilai learning rate optimum adalah 0,01 dengan overall accuracy terbaik disetiap simulasi yang dapat dilihat pada Gambar 4.

Berdasarkan hasil simulasi tersebut maka dapat disimpulkan bahwa nilai learning rate yang semakin besar tidak menjamin akan memberikan hasil klasfikasi yang baik, artinya parameter lainnya mempunyai pengaruh dalam memberikan hasil klasifikasi yang baik. Dengan demikian nilai learning rate saja tidak dapat dijadikan acuan tinggi atau rendahnya hasil klasifikasi. hasil akurasi Parameter training momentum (faktor momentum) menentukan besarnya perubahan bobot dari suatu pelatihan. Setiap perubahan dengan meningkatkan training momentum maka nilai akurasi dari hasil klasifikasi akan mengalami perubahan (Gambar 5).

Momentum dengan nilai 0,5 dianggap memiliki performa yang baik, terlihat dari akurasi yang dihasilkan dengan menggunakan 1 hidden layer, 0,01 learning rate, 0,001 RMS dan 10.000 
iterasi. Sedangkan nilai momentum 0,6 memiliki akurasi yang kurang bagus dengan variasi parameter 1 hidden layer, 0,001 learning rate, 0,001 RMS dan 10.000 iterasi. Dari kedua variasi parameter tersebut di atas, nilai momentum 0,5 menunjukan hasil klasifikasi yang lebih baik dibandingkan dengan momentum 0,6 , akan tetapi hal tersebut tidak terjadi pada kombinasi parameter 1 hidden layer, 0,05 learning rate, 0,001 RMS dan 10.000 iterasi yang menunjukan nilai momentum 0,6 memberikan hasil klasifikasi yang lebih baik dari momentum 0,5 , artinya nilai momentum dipengaruhi oleh parameter lainnya dalam proses klasifikasi penutup lahan.

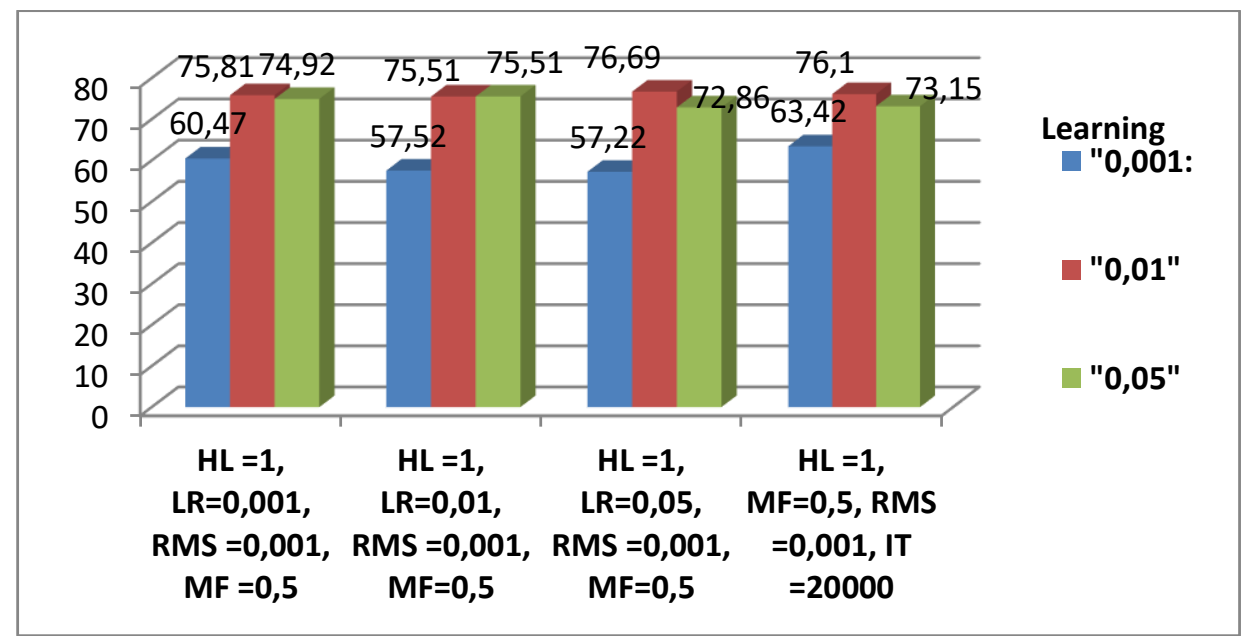

Gambar 4. Hubungan antara learning rate dengan overall accuracy

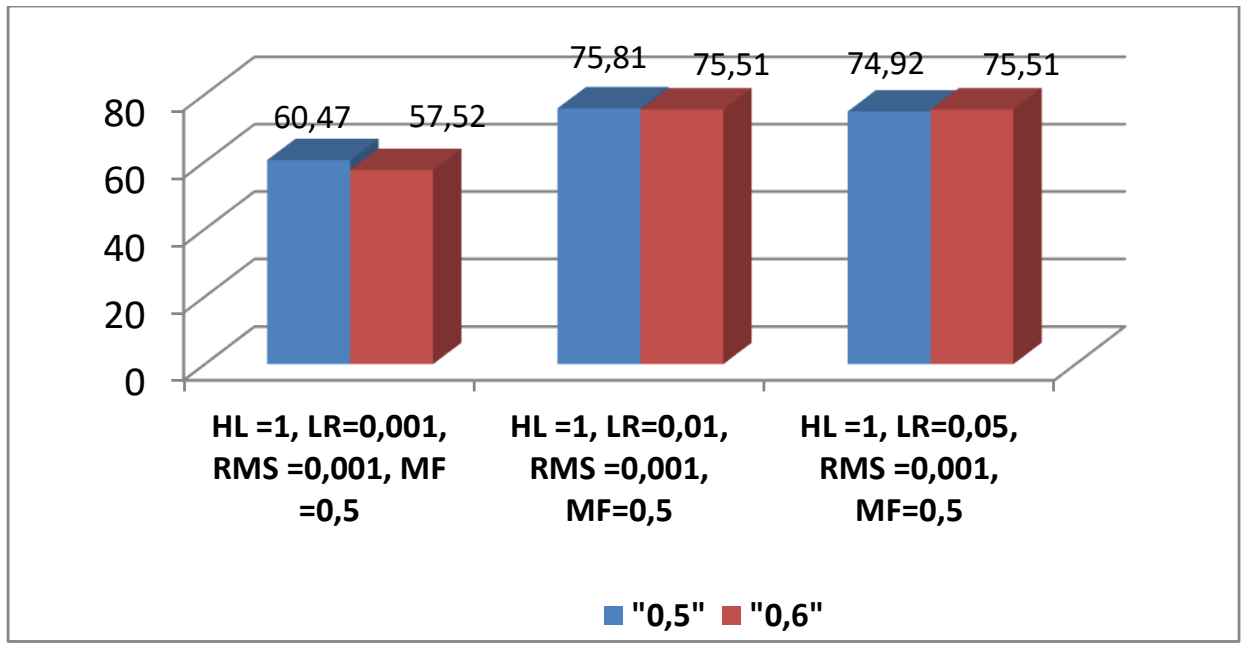

Gambar 6 Hubungan antara training momentum dengan overall accuracy

Parameter terakhir yang berpengaruh terhadap hasil klasifikasi penutup lahan adalah iterasi atau perulangan. Pada metode MLP, proses pembelajaran dan pelatihan jaringan dari suatu data masukan membutuhkan perulangan berkali-kali untuk mengenali, mempelajari dan mengelompokkan pola spectral yang didapat dari training area. Iterasi yang digunakan dalam penelitian ini dimulai dari 10000, 15000 dan 20000. Dari hasil simulasi yang dilakukan, penambahan iterasi dari 10000 menjadi 15000 memberikan nilai akurasi yang paling baik dengan nilai overall accuracy $76,69 \%$, sebaliknya penambahan jumlah iterasi dari 15000 menjadi
20000 menyebabkan terjadinya pengurangan nilai akurasi walaupun tidak begitu signifikan dengan nilai overall accuracy $76,01 \%$. Berdasarkan hasil simulasi tersebut dengan penambahan jumlah iterasi sampai pada batas iterasi optimum akan meningkatkan nilai akurasi hasil klasifikasi dan penambahan jumlah iterasi yang melebihi batas optimum akan menyebabkan penurunan nilai akurasi hasil klasifikasi. Dalam penelitian ini iterasi optimum diperoleh pada iterasi 15000 . Hubungan antara jumlah iterasi dengan nilai overall accuracy ditunjukan pada Gambar 6. Peta hasil klasifikasi penutup lahan dengan metode neural network ditunjukkan oleh Gambar 7. 


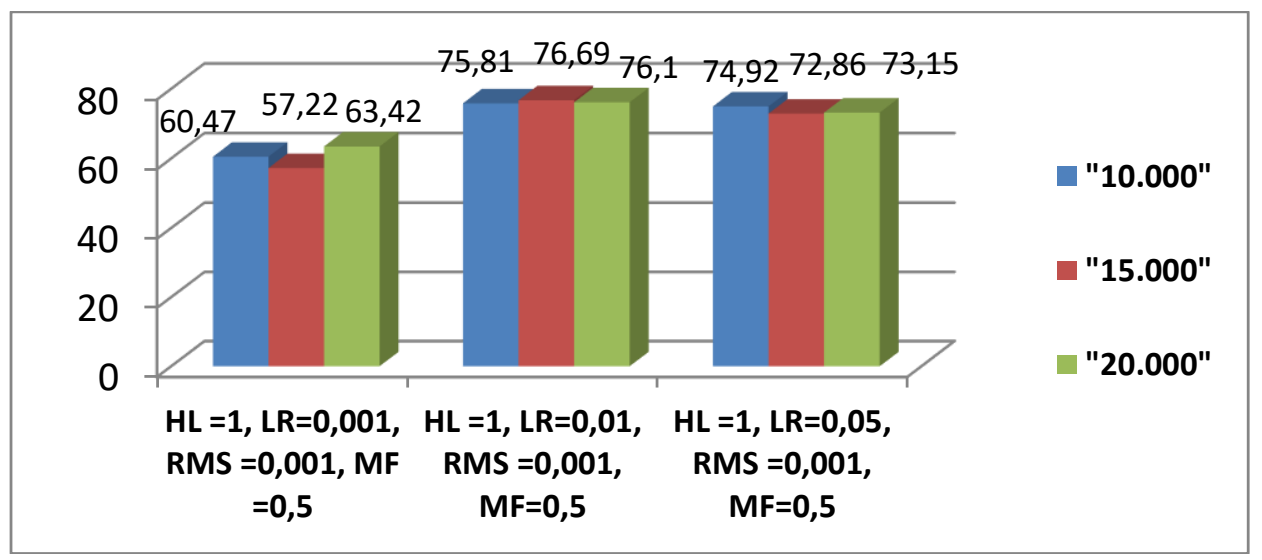

Gambar 7 Hubungan antara Jumlah Iterasi dengan overall accuracy

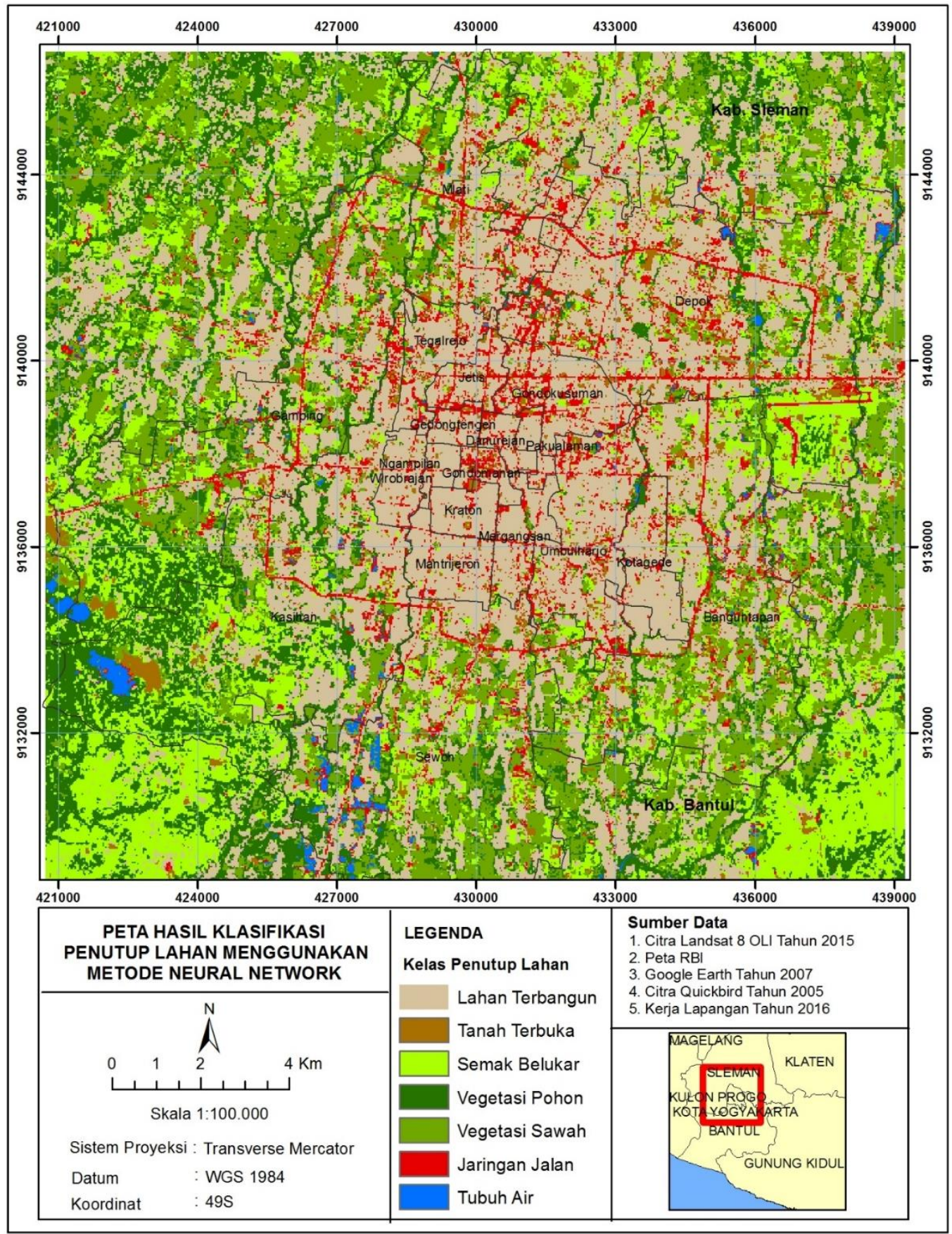

Gambar 8. Peta Hasil Klasifikasi Penutup Lahan Dengan Metode Neural Network 


\section{Simpulan}

Hasil penelitian ini memperoleh kesimpulan bahwa nilai akurasi terbaik yang diperoleh pada metode MLP dengan 7 kelas penutup lahan adalah overall accuracy $76,69 \%$, kappa accuracy 0,722 serta waktu ekseskusi 1,25 menit, dengan kombinasi parameter 1 hidden layer, 0,001 learning rate, 0,5 momentum factor, 0,001 RMS dan 15000 iterasi. Nilai parameter learning rate 0,001 memberikan pengaruh nilai overall accuracy yang rendah sedangkan nilai learning rate 0,01 memberikan nilai overall accuracy yang baik. Iterasi 15000 lebih optimal dibandingkan nilai iterasi 10000 dan 20000 dalam pengaruhnya terhadap nilai akurasi hasil klasifikasi penutup lahan.

Selain kesimpulan tersebut, melalui penelitian ini juga diajukan saran bagi penelitian sejenis maupun berbagai keperluan yang bersifat praktis pada masa yang akan datang, yaitu: (1) pada simulasi jaringan syaraf tiruan untuk input data bisa ditambahkan data non spektral untuk dapat meningkatkan akurasi klasifikasi penutup lahan misalnya dengan menambahkan data lereng, tekstur citra, jenis tanah dan data non spektral lainnya yang memiliki pengaruh terhadap penutup lahan. (2) Kelas Penutup lahan bisa diperinci lagi untuk melihat perbandingan hasil klasifikasi pada setiap level kelas penutup lahan. (3) Pengaturan nilai parameter jaringan dalam MLP dapat lebih bervariasi untuk melihat nilai optimal pada setiap parameter misalnya dengan menambahkan nilai iterasi 10000, 12500, 15000, 17500 dan seterusnya.

\section{Ucapan terima kasih}

Dalam kesempatan ini penulis mengucapkan terima kasih kepada berbagai pihak yang telah membantu dalam penelitian ini, baik selama pengumpulan data, pengolahan, data, maupun analisis data.

\section{Referensi}

Arif, N. (2011). Kajian Kemampuan Jaringan Syaraf Tiruan Berbasis Citra ALOS Dalam Identifikasi Lahan Kritis, Tesis Fakultas Geografi, Universitas Gadjah Mada.

Danoedoro, P. (2012). Pengantar Penginderaan Jauh Digital. Penerbit ANDI, Yogyakarta

Jensen, J. R. (2005). Introductory Digital Image Processing, A remote sensing perspective, $3^{\text {rd }}$ edn, Pearson Prentice Hall, Sidney.

Kusumadewi, S. (2004). Artificial Intelligence, Penerbit Graha IImu, Yogyakarta

Kusumadewi, S. dan Hartati, S. (2010). NeuroFuzzy Integrasi Sistem Fuzzy dan Jaringan Syaraf, Penerbit Graha IImu, Yogyakarta

Lillesand, T. M and Keifer, R. W. (1994). Remote Sensing and Image Interpretation. 3rd. Edition. John Wiley and Sons, Inc. Canada

McCoy, R. M. (2005). Field Methods in Remote Sensing, The Guilford Press, New York. 